\title{
Resource Complementarity for Social Service Delivery: A Case of Corporates and Local Government Authorities in Morogoro, Tanzania
}

\author{
Angela Jesse ${ }^{1} \&$ Kenneth M. K. Bengesi ${ }^{2}$ \\ ${ }^{1}$ Department of Development Studies, College of Social Sciences and Humanities, Sokoine University of \\ Agriculture, Morogoro, Tanzania \\ ${ }^{2}$ Department of Policy Planning and Management, College of Social Sciences and Humanities, Sokoine \\ University of Agriculture, Morogoro, Tanzania \\ Correspondence: Angela Jesse, Department of Development Studies, College of Social Science and Humanities, \\ Sokoine University of Agriculture, P.O. Box 3024, Morogoro, Tanzania. Tel: 255-688-993-627.
}

Received: March 18, 2018 Accepted: June 25, 2018 Online Published: August 21, 2018

doi:10.5539/jms.v8n3p25 URL: https://doi.org/10.5539/jms.v8n3p25

\begin{abstract}
Employing a case study design, this paper examined corporates' resource complementarity to Local Government Authorities in Morogoro region. The findings revealed that as much as corporates such as Kilombero and Mtibwa Sugar Companies comit significant amount of resources through CSR to offer social services, which could otherwise be offered by the LGAs; the LGAs are less informed of the actual contribution made by corporates in terms of the actual budgets spent to complement social services in their areas of jurisdiction. The findings further revealed that poor flow of information from Villages and Wards levels to the District Council has accounted for this challenge, which has resulted into LGAs failing to acknowledge contribution made by the corporates. Failure of LGAs to acknowledge the contribution of Corporates has far reaching impact on the reputation of the corporates and the motivation of corporates to sustain resource complementarity to LGAs. This paper recommends that, there is a need to improve information system within LGAs on the resources complemented by corporates and other stakeholders for social services delivery. Such improvement should encompass production and submission of reports on resources and social services provided through CSRs by development stakeholders to the District Councils.
\end{abstract}

Keywords: Resource complementarity, corporates, corporate social responsibility, Local Government Authorities, social services

\section{Introduction}

The Local Government Authorities (LGAs) are administrative authorities over areas that are smaller than a state, which are close to people hence, they are in a better position to know and serve the needs of communities in their areas of jurisdiction (Fjeldstad, Katera \& Ngalewa, 2010; Makanyeza, 2015; Matimati \& Rajah, 2015). They are only mandated to act within powers delegated to them by legislation or directives of the higher level of government (Komba, Bengesi \& Mwageni, 2018). The LGAs are responsible for maintaining law, order and good governance; promotion of economic and social welfare of people in their jurisdiction; and ensuring effective and equitable delivery of quality and sufficient social services to the people within their areas of jurisdiction ( Komba et al., 2018; Massoi and Norman, 2009; Norman \& Massoi, 2010; Ngamesha, 2013). LGAs use resources, which originate from different sources such as own sources including taxes, funds from the central government and donors including Official Development Assistance (ODA) to provide basic social services such as education, health, water and electricity (OECD, 2016).

Despite access to various sources of funds, LGAs do not have sufficient resources because community demands for social services are increasing over time relative to the available resources (Storey, 2009; Komba et al., 2018; Tshiyoyo \& Koma, 2011). In this case, other public and private sectors including corporate complement resources to LGAs to enable social service delivery to communities and thereby contributing to community development (Rees, Mullins \&Bovaird, 2012; United Nations, 2015). The quest to involve a wode range of stakeholders to contribute to the development resources is based on the fact that community development will not be achieved by the government support alone; it requires supporting hands from other development stakeholders including Corporates through taxes and Corporate Social Responsibility (CSR) (Ng'eni, Bukwimba, 
Kwesibo \& Kaaya, 2015). Through CSR, companies provide social services such as education, health and water to communities (Maliganya \& Bengesi, 2018; Revathy, 2012; Mbirigenda \& Msoka, 2015). CSR is also perceived as among ways of creating good relationship between communities and corporates (Servaes \& Tamayo, 2013; Wang, Tong, Takuechi \& George, 2016). Other motives of CSR are to build corporates' reputation, acceptability and trust to communities (Foote, Gaffney \& Evansa, 2010; Kaufmann \& Olaru, 2012; Jesse \& Bengesi, 2018).

Most existing literature has treated the role of LGAs and companies' CSR in enhancing community development in isolation (Ismail, 2009; Agba, Akwara \& Idu, 2013). Supporting this argument, Jesse and Bengesi (2018) observed that there is still insufficient attention paid to the resources complementarity between LGA and corporates and challenges they face when complementing resources for social service delivery. From this context the paper aims to fill the identified gap by answering the following questions i) how do corporates complement resources to the LGAs for social service delivery in the study area? ii) What are the challenges of resources complementarity for social service delivery in the study area? and iii) what could be the best way to address the identified challenges to ensure efficiently utilization of resources through resource complementarity? The answers to these questions contribute to the understanding of how corporates complement resources to LGAs to ensure reliable social service delivery. The results of this study also provide solutions to the challenges experienced during resource complementarity.

The rest of the paper contain theoretical framework in which the stakeholders theory is used to frame the theme of the study and leads into development of the key questions answered by this paper. The next section is methodology, which describes the research design and data sources for this study. Results and discussion are subsequent sections of the paper, which highlight the major findings and discuss different ways in which LGAs and corporates complement resources for social service delivery in the study area, point out the major challenges of resource complementarity for social service delivery as well as providing ways to address the identified challenges to ensure efficient utilization of resources.

\section{Theoretical Framework}

This study is guided by Stakeholders theory, which was first described by Freeman (1984). Stakeholder theory suggests that business should take into consideration the interests of stakeholders including customers, suppliers, employees, communities and shareholders for achieving corporates objectives (Hamidu, Haron \& Amran, 2015). The stakeholders theory goes beyond the notion of considering shareholder interest that emphasize on profit maximization, by taking into consideration the interest of broad range of stakeholders who contribute to the company's achievements (Pirsch, Gupta \& Grau, 2007; Harrison \& Wicks, 2013). The theory explains corporates' practices of managing stakeholders for maintaining good relationship with them. It is an applicable theory because well-treated stakeholders tend to reciprocate with positive attitudes and behaviors towards an organization. Such reciprocity occurs in the form of sharing valuable information (all stakeholders), purchasing more goods (customers), providing tax breaks (government), providing better financial terms (financiers), purchasing extra stock (shareholders), or working hard and remaining loyal to the organization, even during difficult times (employees) (Harrison, Freeman \& Sá de Abreu, 2015). Therefore, corporates allocate resources to manage their stakeholders such as communities by satisfying their needs and demand than willful concentrating to the productive activities of the business (Harrison, Bosse \& Phillips, 2010).

Stakeholders theory clearly underline that use of company resources to address stakeholders needs is justifiable in managerial activities (Kanji \& Agrawal, 2016). This forms the foundation of CSR in which corporates use resources to serve the community interest for social service. In this case, stakeholders' theory becomes relevance to this study because corporates bring back part of its profit to communities through CSR for legitimacy reason. In serving the interest of communities, corporates provide part of social services, which could have been offered by LGAs (Jesse \& Bengesi, 2018). In this case, corporates complement resources to LGAs by providing social services such as education, water, health and other infrastructure to communities hence the essence of resource complementarity prevail. According to Gulati (1998), resource complementarity involves exchange, sharing and contribution of capital, technology or asset of partners based on the voluntary initiated agreement. It involves contribution of similar and dissimilar resources by different organizations to achieve a certain objective.

\subsection{Role of LGAs and Corporates in Service Provision}

LGAs have a major mandate of facilitating development at the grassroots (Agba et al., 2013; Boris, 2015). Among ways of facilitating development to the people at the grassroot is through rendering social services based on their need. On the other hand, corporates through CSR contribute to community development by ploughing back the generated profit (Ismail, 2009; Ng'eni et al., 2015; Hamad, 2017). However, most of existing literature 
has treated the role of LGAs and companies' CSR in enhancing community development through service delivery in isolation (Ismail, 2009; Agba et al., 2013). Jesse and Bengesi (2018) share similar view that there is insufficient attention paid to explain how resource complementarity occurs between Corporate and LGAs in provision of social services to communities. This raises a question on:

(a) How do corporates complement resources to LGAs for social service delivery in the study area?

The results of this study provide information to the government on the importance of corporates in supporting development initiatives specifically in complementing resources to the LGAs to enable social service delivery. The idea of resource complementarity was also supported by UN development financing conference in Addis Ababa in 2015, which provide a framework for financing sustainable development goal by involving a wide range of stakeholders such as private sector including corporates and other development partners (United Nations, 2015). The widening scope to engage more partners in supporting development is the new initiative intended to complement resources and fast track the execution of the development initiatives in developing countries.

\subsection{Challenges Facing LGAs and Corporates on Resource Complementarity}

Despite resources complemented by corporates to LGAs through CSR for the provision of the social services, literature reports challenges facing LGAs and corporates in fulfilling provision of social services in isolation (Mpambije, 2016; Yuen \& Lim, 2016). For example, scholars have found lack of fund as among challenges facing LGAs in providing social services to communities (Kisumbe, Sanga \& Kasubi, 2014; Jesse \& Bengesi, 2018). Similarly, Yuen and Lim (2016) observed factors related to lack of resources and low willingness of corporate to pay for CSR as significant barriers to implementing strategic CSR to communities. However, literature pays insufficient attention on concurrent challenges associated with resources complementarity between corporates and LGAs in providing social services to communities. This raises a question on:

(b) What are the challenges of resources complementarity for social service delivery in the study area?

(c) What could be the best way to address the identifies challenges?

The results of this question provide insights to address challenges of resource complementarity between Corporates and LGAs to enhance social service delivery to communities.

\subsection{Conceptual Framework}

The conceptual framework shows that LGAs are mandated to provide social services to communities but they face the problem of resource constrains due to the increased number of community needs for social service compared to the available resources. Therefore, through CSR initiatives, corporates among other development partners complement resources to LGAs by giving back part of the profit to communities. Resource complementarity occurs in a situation where corporates complement material and financial resources to LGAs resources. Resource complementarity by the corporates to the LGAs results into the provision of social services such as water, health services, roads, classes rooms and availability of other facilities such as electricity, books, desks and toilets. Therefore resource complementarity for social service delivery between LGAs and corporates is among ways of supporting community development.

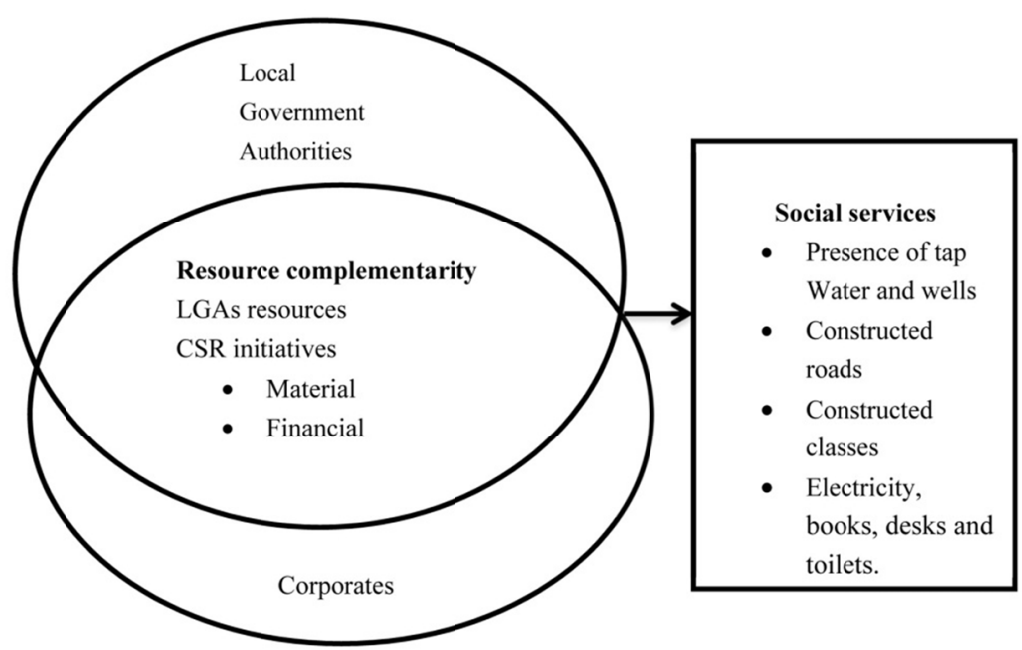

Figure 1. Conceptual framework of the study 


\section{Method}

\subsection{Description of the Study Area}

The study covered four cases including two districts councils namely Mvomero and Kilombero and two Corporates namely Kilombero and Mtibwa Sugar Companies, which are all found in Morogoro region. The region was selected due to availability of companies producing the same product and complementing their resources for social services delivery through CSR in the same region. The selection of two wards and four villages to conduct this study was based on the number of social services resulting from resource complementarity between Corporates and LGAs. The selected wards were Kidatu Ward in Kilombero District where Kilombero Sugar Processing Company is operating and Mtibw in Mvomero District where Mtibwa Sugar Processing Company is operating. Selected villages were Mkamba and Msolwa station found in Kidatu Ward and Madizini and Kidudwe found in Mtibwa Ward.

\subsection{Case Study Design and Sources of Data}

This study employed a case study design. According to Puch (2005) Case study design allows in-depth investigation of phenomena. Therefore, the use of case study was appropriate in this study because it provide time to build trust to participants as well as allowing in-depth understanding of how LGAs and sugar companies among other stakeholders complement resources to LGAs for social service delivery and the challenges associated with the process.

Primary data were collected from the Key informant interviews and focus group discussions. The key informants included Executive Officers (CEOs) of Kilombero and Mtibwa sugar companies, District Executive Directors (DEDs), Ward Executive Officers (WEOs), Ward Councilors, Heads of Departments in councils and head teachers/masters/mistress. Other key informants were Village Chairpersons, Village Executive Officers, Community Development Officers, Health Officers, doctors and Education Officers at ward level. A number of 42 key informants provided information for the study. Information collected from the key informants was about resources complemented to LGAs by sugar companies to enable social service delivery in the study area. Other collected information revealed how the LGAs acknowledged the efforts of corporates of complementing resources to LGAs by implementing CSR activities in the study area.

The study involved four FGDs one from each village. Each FGD included 8 to 10 participants who were the members of village councils. The FGD participants were randomly selected because they all participate in issues concerning communities in the village council. Interview guide was used to collect data from the key informant interviews and focus group discussions where tape recorder was used to record the information. Face to face interviews were conducted at first sight then phone calls were made to the same key informant following identification of gaps during data transcription. Secondary data including CSR activities implemented to communities was collected from companies' offices.

\subsection{Data Analysis}

Conventional content analysis was used to analyze the primary data. The analysis involved two steps. The first phase constituted data organization, generation of themes and data coding. In this step, the recorded interviews conducted in Kiswahili language were transcribed and translated into English language and were systematically organized. The organization was based on themes relevant to this study. The themes were; resources complemented by companies to LGAs, sharing of information on CSR activities, challenges faced in complementing resources. The second step was testing data by relating information from different sources (Triangulation). The information was compared with literature for gaining comprehensive knowledge.

\section{Results}

This section presents results on corporate and LGAs resource complementarity for social service delivery in the study area. The results answered the following questions; (a) how do LGAs and corporates complement resources for social service delivery in the study area? (b) What are the challenges faced in complementing resources to enable service delivery in the study area? c) What could be the best way to address these challenges to ensure efficient utilization of resources through resource complementarity?

\subsection{District Councils and Sugar Companies Resource Complementarity}

Exploring resource complementarity between Kilombero and Mvomero District Councils and Kilombero and Mtibwa Sugar Companies for social service delivery results in table 1 presents various social services such as bbuildings, infrastructure, supply of equipment and electricity. 
Table 1. Resource complementarity between LGAs and companies

\begin{tabular}{|c|c|c|}
\hline Social services & $\begin{array}{l}\text { Resourses complemented by Kilombero Sugar } \\
\text { Company to Kilombero District council }\end{array}$ & Kilombero District Council Resources \\
\hline Nyandeo health center & $\begin{array}{l}\text { Built four patient wards } \\
\text { Built a Mortuary } \\
\text { Built a theatre equipped with operating facilities }\end{array}$ & $\begin{array}{l}\text { Built two patient wards in collaboration with community } \\
\text { members } \\
\text { Built a laundry }\end{array}$ \\
\hline Mtukula Primary school & Built one class equipped with desks & Built other classes in collaboration with community members \\
\hline $\begin{array}{l}\text { Nyandeo secondary } \\
\text { school }\end{array}$ & $\begin{array}{l}\text { Provided five computers } \\
\text { Built three class rooms } \\
\text { Provided a mobile laboratory }\end{array}$ & $\begin{array}{l}\text { Built administration block in collaboration with community } \\
\text { members and other stakeholders including TANECSO } \\
\text { Built three class rooms in collaboration with community } \\
\text { members }\end{array}$ \\
\hline Social services & $\begin{array}{l}\text { Resource complemented by Mtibwa Sugar } \\
\text { Company to mvomero district council }\end{array}$ & Mvomero District Council resources \\
\hline $\begin{array}{l}\text { Nassoro Seif secondary } \\
\text { school }\end{array}$ & $\begin{array}{l}\text { Built four classes } \\
\text { Administration block } \\
\text { Electricity } \\
\text { Shallow wells construction } \\
\text { Provided temporary accommodation for teachers } \\
\text { and other staff at the company buildings }\end{array}$ & Built two class rooms in collaboration with communities \\
\hline $\begin{array}{l}\text { Mtibwa Secondary } \\
\text { school }\end{array}$ & $\begin{array}{l}\text { Provided } 30 \text { bags of cement for building } \\
\text { laboratory } \\
\text { Built administration block } \\
\text { Offered game and sport jersey }\end{array}$ & $\begin{array}{l}\text { Provided the remaining materials and built laboratory in } \\
\text { collaboration with community members }\end{array}$ \\
\hline
\end{tabular}

In view of results in table 1 it is evident that most of resources were complemented in health and education services. For example Kilombero Sugar Company complemented resources in building Nyandeo health center by building four patient wards, a Mortuary and a theatre equipped with equipments. The government constructed two patient wards in collaboration with community members and a laundry in Nyandeo health center. On the other hand, Mtibwa Sugar Company complemented resources to Nassoro Seif Secondary school where the company constructed four classes, administration block, provided electricity, provided water by sponsoring well construction as well as providing temporary accommodation for teachers and other staff at the company buildings. The government in collaboration with the community members constructed two classes at Nassoro Seif Secondary School. Other complemented resources by sugar companies are construction of classes, administration blocks, construction of wells and other equipments including computers.

Table 2. CSR activities provided by Kilombero and Mtibwa sugar companies

\begin{tabular}{lll}
\hline Kilombero sugar company & Place & Amount (Tsh) \\
Social service & Nyandeo & $300,000,000 /=$ \\
\hline Upgrading government health and facilities & Tumaini primary school, Mang'ula "A" village & $16,552,700 /=$ \\
Construction of one classroom with furniture & Mtukula Primary school, Msolwa station village & $16,552,700 /=$ \\
Construction of one classroom with furniture & Kiswanya primary school, Mang'ula village & $2,300,000 /=$ \\
Fabrication of 50 desks & Sabasaba primary school, Kiberege & $2,300,000 /=$ \\
Fabrication of 50 desks & Sanje Secondary School, Sanje & $3,000,000 /=$ \\
Construction of pit latrines & Mwanihana Secondary School, Mkula & $3,000,000 /=$ \\
Construction of pit latrines & & $106,284,600 /=$ \\
Development of a new block farm & & $\mathbf{4 5 0 , 0 0 0 , 0 0 0 / =}$ \\
\hline Total & Place & $\mathbf{A m o u n t ~ ( T s h ) ~}$ \\
\hline Mtibwa sugar company & NassorSeif Sec. School, Mtibwa, Turiani & $85,000,000$ \\
\hline Class rooms, Laboratory, Play grounds, utilities, etc & $28,000,000$ \\
Class rooms, Playground, Etc. & Mtibwa Sec School, Mtibwa, Turiani & $75,000,000$ \\
All buildings, and their maintenance, utilities, etc & Mtibwa Primary School & $15,000,000$ \\
Construction of Class rooms 2007 & Sungaji Primary School, Turiani & $6,000,000$ \\
Construction of Class rooms, 2007 & Kanga Sec. School - Kanga & $5,000,000$ \\
Materials for construction of rooms & MuradSadiq Sec. School, Turiani & $105,000,000$ \\
All buildings and Maintenance & Kiwandani Primary School - MtibwaTuriani & $3,000,000$ \\
Play grounds, farm for sugar cane and Maize & Kidudwe Primary School - Mtibwa, Turiani & $3,000,000$ \\
Play Grounds, etc & Diyongoya Sec. School, Turiani & $1,500,000$ \\
Farm & MnaziMmoja Primary School - Mtibwa, Turiani & $\mathbf{3 2 6 , 5 0 0 , 0 0 0 / =}$ \\
\hline Total & & \\
\hline
\end{tabular}

Table 2 presents some of CSR activities implemented by sugar companies to communities in the study area. The results show the amount of money in Tshs spent by sugar companies to implement CSR activities to 
communities. Kilombero Sugar Company spent 450,000,000/= to construct health center, classroom, provide desks, pit latrines among other services as shown in Table 2. On the other hand, Mtibwa sugar company spent $326,500,000 /=$ to construct play grounds, materials for construction classes, building and maintanence of schools among other services.

\section{Discussion}

\subsection{District Councils and Sugar Companies Resource Complementarity}

The resource complementarity between Corporates and LGAs was examined to explore different resources complemented by sugar companies to LGAs in the study area to enable social service delivery. Results in Table 1 show the resource complemented by Kilombero and Mtibwa sugar companies to Kilombero and Mvomero district councils for social service delivery. Resource complementarity in the study area was observed mainly in health and education services. Nyandeo health center is a good example of major social services found in Kidatu Ward at Mkamba village and is an outcome of resource complementarity between Kilombero Sugar Company and Kilombero district council. The key informant from Health Department at Kilombero District Council reported that;

“...Kilombero Sugar Company is currently building a health center called Nyandeo health center at Kidatu Ward” (Health Officer, Kilombero District Council, August, 2015).

Other key informants from Kidatu Ward and Mkamba Village reported that Nyandeo Health Center was initiated by community members as one of their priorities. According to them, patients were previously treated at Mikumi hospital which is too far (about 35 to $40 \mathrm{~km}$ ) from their residence. Hence, having a health center in their ward was the best solution to maintain their health status. Consistent to community need for health center, Kilombero Sugar Company decided to complete the construction of the buildings starting from where community members and the government ended. A key informant from Nyandeo Health Center confirmed its existence by reporting that;

"Kilombero Sugar Company built patient wards, mortuary and a theatre accompanied by its equipment. The company is now planning to build workers houses. However, there are other buildings including two patient wards which were built by the community members and Kilombero District Council. There is also a laundry which worth Tsh 40,000,000/=, which was built by the government itself' (Health Officer, Nyandeo Health Center, Kidatu Ward, August, 2015).

This quote indicates that the government resource used to construct Nyandeo health center were complemented not only by Kilombero Sugar Company but also by the community members. This implies prevalence of good relationship between community members, Kilombero District Council and Kilombero Sugar Company. Such relationship has contributed to saving lives of community members through the established health center (Ringo, Bengesi \& Mbago, 2018a). The presence of health center contributes to development because health people contribute their efforts to development (Ringo, Bengesi \& Mbago, 2018b; Vogl, 2012).

Nyandeo health center was considered as a big project, which saves lives of people in Kidatu Ward. For example, focus group discussion conducted in Mkamba village at Kidatu ward in Kilombero district council revealed that "before establishment of Nyandeo health centre, most women were dying in the delivering process particularly those who gave birth through operation. The health centre is now having qualified doctors and is equipped with a very good theatre which serves pregnant women and other patients" This implies that presence of health centre improves health of the community members. It also contributes to the success of the organization because healthy people are capable of producing and supplying raw materials for the company and are also capable of working in the company for meeting objectives of profit maximization. According to Safkaur (2016), corporate profit has a very close relationship to people's lives. For example, part of profit provided by Kilombero Sugar Company through CSR for constructing Nyandeo health centre contribute in addressing community health problems. This is consistent with the stakeholders' theory which goes beyond the notion of considering shareholders' interest on profit maximization and takes into consideration the interest of broad range of stakeholders who contribute to the company's achievements (Bengesi, 2013; Pirsch et al., 2007). However, consideration of interests of community members including need for social services by companies does not only contribute to the company achievement but also to community development.

Results also show that, resources complemented by Sugar Campanies to LGAs were also observed in education services as shown in Table 1. For example the key informant from Nassoro Seif at Mtibwa ward in Mvomero district council reported that,

"Mtibwa Sugar Company has done a lot to our school. For instance, 90\% of the school buildings have been 
built by the company. These buildings include classes and teachers offices. The government and the community members together built one block with two classes in this school. The company offered a plot where this school is built. This is the reason of calling this school Nassoro Seif secondary school which reflects the name of one among the owners of the company. Mtibwa Sugar Company is supporting in providing many services in this school such as electricity and water which is obtained from a well-constructed with financial support of the company. Mtibwa Sugar Company is also providing accommodation to the school staffs..." (Key informant, Nassor Seif Secondary School, Mtibwa Ward, Mvomero District, August, 2015).

Another key informant from Mtukula primary added that;

“... Kilombero Sugar Company built one classroom and equipped with desks. This classroom is used by standard seven pupils. Other classes were built in collaboration between the community members and the government. As I am talking to you now, we have written a letter to the company requesting them to assist us to cover the cost for conducting standard seven farewell party this year. We are grateful to have Kilombero Sugar Company in our area." (Key informant, Mtukula Primary School, Msolwa station village, Kidatu wards, Kilombero District Council, August, 2015)

The quotes above reveals resource complementarity between community members, Kilombero district council and Kilombero sugar company as well as Mvomero district councils and Mtibwa sugar companies in education services. Resource complementarity creates a greater synergy between sugar companies, LGAs and the community members. This synergy results in fostering development through improved social service delivery. Moreover, resource complementarity is among ways which corporate use in bringing communities closer to business for achieving companies' objectives while supporting community development (Bengesi, 2013; Ismail, 2009; Kadlubek, 2015). In this case, the study in one hand supports stakeholders' theory which states that, business should take into consideration the interests of stakeholders for achieving corporates objectives. On the other hand, resource complementarity between LGAs and sugar companies is among ways supporting development to communities. The idea of resource complementarity is also supported by Public Private Partnership Policy of 2008 which emphasises the need for private sectors to contribute resources to support social services to communities.

Results in Table 2 present the CSR activities implemented by Kilombero and Mtibwa sugar companies through CSR activities. Services provided by Kilombero and Mtibwa sugar companies are the government obligations therefore, providing them reduces the burden to LGAs within which companies are situated.The LGAs in the study area are aware that corporates are supporting social service delivery to the surrounding communities through CSR. However, the LGAs do not have information on the value of all complemented resources in financial terms as stipulated in Table 2. Understanding of the cost incurred by sugar companies provide an indication of the amount of money that could have been allocated to the same activity by the LGAs. Having documented information indicating the amount of resources contributed by development stakeholders is among ways of recognising their effort for supporting community development. Therefore, there is a need for documented information by LGAs to reveal how much has been contributed by other development partners including sugar companies. Recognition of companies' effort is a motivation for providing more support in addressing community needs.

Such recognition is vital to corporates because it creates positive image to the government and ensure good reputation to both government and the community. According to Mishra and Suar (2010), building corporates reputation, acceptability and being trusted by communities are among motives of CSR. Hence, implementation of CSR activities is among ways of winning trust of communities against other business rivals (Jankalova, 2016).

\subsection{Challenges of Resource Complementarity between LGAs and Sugar Companies}

One major challenge resulting from resource complementarity between district councils and sugar companies in the study area is the communication gap, which does not enable the LGA to fully understand the CSR activities carried out by sugar companies and other stakeholders in areas of their jurisdiction and even when they know the activities they are not informed of the actual budget spent on CSRs. For example, the key informant from Mvomero district reported that;

"Mtibwa Sugar Company is supporting the surrounding communities therefore; more information can be obtained from places where the assistance was provided. But there are some of them which are known for example, Mtibwa Sugar Company has constructed Nassoro Seif secondary school as well as providing other facilities including electricity and water. The company has also supported Mtibwa secondary in building some classes and offices. The company is also doing the maintenance of roads passing within 
community residences" Key informant 4, Community Development Department, Mvomero District Council, August, 2015)

The quote implies that Mvomero district council is aware that Mtibwa Sugar Company is supporting the surrounding communities yet the study observed that the district was not aware of some CSR activities performed by Mtibwa Sugar Company to support the surrounding communities. This indicates weakness in reporting CSR activities carried out by development partners including sugar companies. The evidence for absence of information at the district level in Mvomero district councils was also reported by key informant from education department at Mvomero district council that;

"...you need to give us time to call the head teachers/masters/mistress so we can ask how much Mtibwa Sugar Company has contributed then we will be in a good position to have a discussion with you" (Key informant 5, education department, Mvomero District Council, August, 2015).

The quotes further confirm absence of records of CSR activities at the district council. It implies that there is weakness in reporting CSR activities in Mvomero District council. Under normal circumstances, government officials at the village and Ward level are supposed to report whatever is happening within their areas to the district councils, particularly to the respective departments; but this is not always the case. This situation may provide loopholes for misuse of some resources specifically when the LGAs and corporates direct resources to the same activity. Failure of LGAs to document and report CSR activities carried out by development stakeholders such as Mtibwa Sugar Company may result in duplication of social services which translate into wastage of resources.

Likewise, there are other social services offered by Kilombero Sugar Company in Kidatu Ward which were not documented and reported at Kilombero District Council. Such unreported social services include water project. Key informant at Kidatu Ward reported that,

“..Kilombero Sugar Company supported water project which cost 15 million. The company also did the maintenance of Ward and Police offices at Kidatu Ward..." (Key informant 2, Kidatu Ward, August, 2015).

The discrepancy of information about social services delivered can create room for misuse of resources. For example, the government may allocate resources to the projects where the company has invested already. Either the missing information at the district council level can bring incorrect impression to companies and other development stakeholders that the government does not appreciate their support to communities. Lack of appreciation about CSR activities may decrease the motivation of companies to continue providing support to communities. Appreciating what corporate does to support development through CSR create positive image of the company and is among ways of winning competitors (Servaes \& Tamayo, 2013).

\section{Conclusion and Recommendations}

\subsection{Conclusion}

This paper has shown that through CSRs, corporate such as sugar companies play an important role in complementing resources for provision of social services that could have been offered by LGAs, which are legally mandated to offer the services. In one hand, considering community interests in providing social services through CSR initiatives contributes to the success of the company but on the other hand, it contribute to community development. Thus, results of this study contribute to the stakeholder's theory that, consideration of interests of stakeholders does not only lead to corporate success but also to community development.

The study concludes further that information flow between district level and local levels is weak because some of the social services offered by the companies through CSRs were not known at district level. This information gap may leads to duplication of social services, which translate into wastage of resources because the same activity may be funded at the same time by corporates and LGAs. Either, the LGAs were found not to have reports on the amount contributed by sugar companies through CSR to their plans for social service provision in their areas of jurisdictions. This scenario suggest that it makes difficulty for the LGA to account how much value of social services offered by the corporates complement the LGA budget.

\subsection{Recommendations}

The study recommends that, there is a need to improve information flow between LGAs at district, ward and village levels and corporate regarding resource complementarity for social services delivery. Such improvement should encompass production and submission of reports on resources and social services provided through CSRs by development stakeholders to the District Councils. Improved communication will avoid the possibility of double allocation of resources to the same development activity that leads to duplication of social service, which 
translates into wastage of resources. The improved communication can also provide opportunity for LGAs to sufficiently appreciate corporates efforts of providing social services to communities thereby act as motivation for more supports.

The study contributes to the Local Government Act of 1982 on the need to direct the LGAs to formulate bylaws that guide development stakeholders to report CSR contributions in financial terms to respective district councils The Act should clarify that every LGA need to document and report the value of resources complemented by development stakeholders in financial terms. This will act as a motivation to development partners to continue supporting communities' through CSRs.

\section{Acknowledgments}

We would like to thank Ardhi University for financially supporting this study. We would also like to thank the management of Kilombero and Mtibwa Sugar Companies for providing research information. We appreciate the Local government officials- Ward Executive Officers, Village Executive Officers, Chair persons, Community Development Officers, Planning Officers, Councilors, Health Officers, Teachers in Kilombero and Mvomero District Councils for your Cooperations.

\section{References}

Agba, M. S., Akwara, A. F., \& Idu, A. Y. (2013). Local Government and Social Service Delivery in Nigeria: A Content Analysis. Academic Journal of Interdisciplinary Studies, 2(2), 455-462. https://doi.org/10.5901/ajis.2013.v2n2p455

Bengesi, K. M. K. (2013). Strategic Entrepreneurial Response of Small and Medium Enterprises. PhD. University of Pretoria.

Boris, O. H. (2015). Challenges confronting local government administration in efficient and effective social service delivery: the Nigerian experience. International Journal of Public Administration and Management Research (IJPAMR), 2(5), 12-22.

Fjeldstad, O., Katera, L., \& Ngalewa, E. (2010). Planning in Local Government Authorities in Tanzania: Bottom-up Meets Top-down. Research on Poverty Alleviation (REPOA), 18, 1-8.

Footea, J., Gaffney, N., \& Evansa, J. R. (2010). Corporate social responsibility: Implications for performance excellence. Total Quality Management, 21(8), 799-812. https://doi.org/10.1080/14783363.2010.487660

Freeman, R. E. (1984). Strategic Management: A stakeholder Approach. Boston, MA: Pitman.

Gulati, R. (1998). Network location and learning: The influence of network resources and firm capabilities on $\begin{array}{llll}\text { alliance formation. Strategic Management Journal, } & \text { 20, 397-420. }\end{array}$ https://doi.org/10.1002/(SICI)1097-0266(199905)20:5<397::AID-SMJ35>3.0.CO;2-K

Hamad, B. H. (2017). Corporate Social Responsibility (CSR) in the shipping industry: A distribution mechanism between Maritime Security needs and Seafarers' Welfare. Studies of Organizational Management \& Sustainability, 3(1), 1-13.

Hamidu, A. A., Haron, M., \& Amran, A. (2015). Corporate Social Responsibility: A Review on definitions, core characteristics and theoretical perspectives. Mediterranean Journal of Social Sciences, 6(4), 83-95. https://doi.org/10.5901/mjss.2015.v6n4p83

Harrison, J. S., \& Wicks, A. C. (2013). Stakeholder Theory, Value, and Firm Performance. Business Ethics Quarterly, 23(1), 97-124. https://doi.org/10.5840/beq20132314

Harrison, J. S., Bosse, D. A., \& Phillips, R. A. (2010). Managing for stakeholders, stakeholder utility functions and competitive advantage. Strategic Management Journal, 31, 58-74. https://doi.org/10.1002/smj.801

Harrison, J. S., Freeman, R. E., \& Sá de Abreu, M. C. (2015). Stakeholder Theory as an Ethical Approach toEffective Management: applying the theory to multiple contexts. Review of business management, 17(55), 858-869. https://doi.org/10.7819/rbgn.v17i55.2647

Ismail, M. (2009). Corporate social responsibility and its role in community development: An international perspective. The Journal of International Social Research, 2(9), 199-209.

Jankalova, M. (2016). Approaches to the evaluation of Corporate Social Responsibility. Economics and Finance, 39, 580-587. https://doi.org/10.1016/S2212-5671(16)30302-1

Jesse, A., \& Bengesi, K. M. K. (2018). Planning Interface for Social Service Delivery between Local Government Authorities and Corporates in Morogoro, Tanzania. International Journal of Business, 
Humanities and Technology, 8(3), 68-80. https://doi.org/10.30845/ijbht.v8n1a6

Kadlubek, M. (2015). The essence of corporate social responsibility and the performance of selected company. Social and Behavioral Sciences, 213, 509-515. https://doi.org/10.1016/j.sbspro.2015.11.442

Kanji, R., \& Agrawal, R. (2016). Models of Corporate Social Responsibility: Comparison, Evolution and Convergence. IIM Kozhikode Society \& Management Review, 5(2), 141-155. https://doi.org/10.1177/2277975216634478

Kaufmann, M., \& Olaru, M. (2012). The impact of corporate social responsibility on business performancecan it be measured, and if so, how? The Berlin International Economics Congress, $7^{\text {th }}-10^{\text {th }}$ March, 2012, p. 16.

Kisumbe, L., Sanga, D., \& Kasubi, J. W. (2014). More than a decade of decentralization in Tanzania: Its implications on Pro-poor service delivery. The case of primary education and health services. International Journal of Scientific and Research Publications, 4(12), 1-8.

Komba, A. M., Bengesi, K. M. K., \& Mwageni, T. (2017). Planning: Concept, Theories and Models. In C. Lifuliro, I. Zilihona, T. Mdendemi, A. Kamanzi, G. Kinyashi, \& van T. Djik (Eds.), Tanzania Planners' Handbook: A guide for Development Planning (pp. 31-41). African Studies Center, Leiden, Netherlands.

Makanyeza, C., Kwandayi, H. P., \& Ikobe, B. N. (2015). Strategies to improve service delivery in local authorities. International Journal of Information Technology and Business Management, 5(1), 1-11.

Maliganya, W., \& Bengesi, K. M. K. (2018). Policy Enabling Environment of Mining Sector in Tanzania: A Review of the Opportunities and Challenges. Journal of Sustainable Development, 11(4), 1-12. https://doi.org/10.5539/jsd.v11n4p1

Massoi, L., \& Norman, A. S. (2009). Decentralization by devolution in Tanzania: Reflections on community involvement in the planning process in Kizota Ward in Dodoma. Journal of Public Administration and Policy Research, 1(7), 133-140.

Matimati, P. T., \& Rajah, N. (2015). The use of e-governance by local authorities to improve service delivery: A case of Chitungwiza municipality. Journal of Global Research in Computer Science, 6(12), 1-10.

Mbirigenda, S. K., \& Msoka, C. T. (2015). Community development through corporate social responsibility: some issues from selected companies in Tanzania. Syllabus Review, 6(1), 99-125.

Mishra, S., \& Suar, D. (2010). Does Corporate Social Responsibility Influence Firm Performance of Indian Companies? Journal of Business Ethics, 95, 571-601. https://doi.org/10.1007/s10551-010-0441-1

Mpambije, C. J. (2016). Decentralization of Health Service Provision in Tanzania: Are Local Government Authorities Improving Anyway? Evidence from Local Government Authorities Audit Reports. International Journal of Social Science and Humanities Research, 4(3), 461-472. Retrieved from www.researchpublish.com

Ng'eni, F. B., Bukwimba, M. L., Kwesigabo, E. M., \& Kaaya, I. D. (2015). The Role of Corporate Social Responsibility (CSR) in Community Development in Tanzania. American Journal of Economics, 5(6), 609-615.

Ngamesha, B. A. (2013). Effects of education decentralization by devolution on students' performance in Tanzania: the case of community secondary schools in Temeke municipality. A Dissertation submitted for the award of Masters of Education in Administration, Planning and Policy studies at Open University, Tanzania.

Norman, A. S., \& Massoi, L. (2010). Decentralization by devolution: Reflections on community involvement in planning process in Tanzania. Educational Research and Reviews, 5(6), 314-322. Retrieved from http://www.academicjournals.org/ERR2

OECD. (2016). Official Development Assistance. Issue Brief Series. https://doi.org/10.1787/factbook-2015-83-en

Pirsch, J., Gupta, S., \& Grau, S. L. (2007). A framework for understanding corporate social responsibility programs as a continuum: An exploratory study. Journal of Business Ethics, 70, 125-140. https://doi.org/10.1007/s10551-006-9100-y

Punch, K. F. (2005). Introduction to Social Research-Quantitative \& Qualitative Approaches. London: Sage. Retrieved from http://www.qualitative-research.net/index.php/fqs/article/view/109/227 
Rees, J., Mullins, D., \& Bovaird, T. (2012). Third sector partnerships for public service delivery: an evidence review. Working paper No $60 . \quad$ Retrieved from https:/www.birmingham.ac.uk/generic/tsrc/documents/tsrc/working-papers/working-paper-60.pdf

Revathy, B. (2012). Corporate Social Responsibility - An Implementation Guide for business. Far East Journal of Psychology and Business, 6(2), 15-31.

Ringo, J. J., Bengesi, K. M. K., \& Mbago, M. C. Y. (2018a). Access and Challenges of Health Facilities amongst Agro-pastoralist Communities in Handeni District, Tanzania. Journal of Population and Social Studies, 26(1), 153-167

Ringo, J. J., Bengesi, K. M. K., \& Mbago, M. C. Y. (2018b). Gender Determined Roles and Under-Five Mortality among Agro-pastoralist Communities in Handeni District, Tanzania. Journal of Population and Social Studies, 26(3), 218-229. https://doi.org/10.25133/JPSSv26n3.014

Safkaur, O. (2016). Corporate Social Responsibility in the Health Sector for Papua Indonesia. International Journal of Scientific \& Technology Research, 5(4), 159-167.

Servaes, H., \& Tamayo, A. (2012). The Impact of Corporate Social Responsibility on Firm Value: The Role of Customer Awareness. Retrieved from https://www.tias.edu/docs/default-source/documentlibrary_fsinsight/research-paper-servaes-and-tamayo-.pd $\mathrm{f}$

Storey, D. (2009). Can International Local Government Partnerships Make a Difference? Lessons from the Australia - Papua New Guinea Good Practice Scheme. Commonwealth Journal of Local Governance, 3, 68-91. https://doi.org/10.5130/cjlg.v0i0.1110

Tshiyoyo, M. M., \& Koma, S. B. (2011). Local Government Public Service Delivery in Africa; A Comparative Perspective. African Journal of Public Affairs, 4(2), 119-130.

Vogl, T. S. (2012). Education and Health in Developing Economies. Retrieved from https://www.princeton.edu/ tvogl/vogl_ed_health_review.pdf

Wang, H., Tong, L., Takeuchi, R., \& George, G. (2016). Corporate Social Responsibility: an overview and new research directions. Academy of Management Journal, 59(2), 534-544. https://doi.org/10.5465/amj.2016.5001

Williamson, A. L., Burke, B. F., \& Beinecke, R. H. (2010). Public Service and Social Responsibility: A Role for Public Affairs in Undergraduate Business Education. Journal of Public Affairs Education, 17(3), 367-384. https://doi.org/10.1080/15236803.2011.12001650

Yuen, K. F., \& Lim, J. M. (2016). Barriers to the Implementation of Strategic Corporate Social Responsibility in Shipping. The Asian Journal of Shipping and Logistics, 32(1), 49-57. https://doi.org/10.1016/j.ajs1.2016.03.006

\section{Copyrights}

Copyright for this article is retained by the author, with first publication rights granted to the journal.

This is an open-access article distributed under the terms and conditions of the Creative Commons Attribution license (http://creativecommons.org/licenses/by/4.0/). 